\title{
NOTE.
}

\section{NOTE ON THE STRUCTURE OF TRIGONOCARPON OLIVAEFORME.-}

The seed with which the present preliminary note is concerned will be spoken of provisionally by the name Trigonocarpon olivaeforme, familiar to palaeobotanists from the work of Williamson. The question of the specific relation of the petrified specimens under consideration to the seeds preserved as casts, will be left open at present.

The structure of Trigonocarpon was first described by Hooker and Binney in $1855^{1}$, and subsequently by Williamson in $1877^{\circ}$. From the works of these authors a good knowledge of the more general features in the anatomy of the seed has been obtained. Much more recently, in 1900, the late Mr. George Wild published an interesting paper dealing chiefly with the structure of the micropylar region and of the outermost layers of the testa, and in 1904 ", Prof. F. W. Oliver gave an account of the French petrified specimens of Trigonocarpus pusillus originally described by Brongniart. Our own work is entirely based on specimens from the British - Coal-Measures, which appear to be at least specifically distinct from the French forms.

In the present note, without entering further into the literature of the subject, we propose to give in the first place a short general account of the structure of the seed, and then to place on record the chief results of our own investigations, leaving a more detailed and illustrated description, as well as any theoretical points involved, for a later opportunity. Trigonocarpon olivaeforme, which is not uncommon in the calcareous nodules of the Lower Coal-Measures of Britain, is a large seed of ovate form, the body of the seed commonly measuring at least $20 \mathrm{~mm}$. in length by $16 \mathrm{~mm}$. or more in its greatest diameter. The general transverse section is approximately circular and radially symmetrical, so that Trigonocarpon is a typical member of the Radiospermeae of Prof. F. W. Oliver ${ }^{b}$. The micropylar region was of great length, fully equal to that of the body of the seed, so that a full-sized specimen when complete would have measured from 40 to $50 \mathrm{~mm}$. from end to end. This is shown, for example, in a fine specimen of the complete seed (T. Parkinsoni), in the Hutton Collection at Newcastle ${ }^{\circ}$.

1 On Trigomocarpons contained in nodules of Limestone. Phil. Trans., vol. cxlv, p. I 49.

- Organization of Fossil Plants of Coal-Measures, Part VIII, Phil. Trans., vol. clxvil, p. 248.

- On Trigonocarpon olivagorme, Trans. Manchester Geological Society, Part XV, vol. xxvi. No. 4.

- On two Palacozoic Seeds, Trigonacarpus and Polylopkospermum, New Phytologist, vol. iii,

Stracture and Affinities of Stephanospermum, Brongniart. Trans. Linnean Soc., vol. vi (Botany), 1904.

- Figured in Lindley and Hutton, Fossil Flora, Pl. 87, Flg. 3; Photograph in Scott, Wilde Lectare, On the Early History of Seed-bearing Plants, Memoirg and Proceedings Manchester Literary and Philosophical Society, rol. xlix, I905. Pl. III, Fig. 4.

[Annais of Botany, Vol. XX. No. LXXVIL. January, 1906] 
The seed, as is well known, possesses a very thick two-layered testa, the inner zone of which, the endotesta or sclerotesta, consists of sclerotic tissue many cells in thickness; its more external elements are commonly elongated in the radial direction. The sclerotesta bears three sharp and prominent longitudinal ridges on its outer surface with corresponding furrows on the inner side, marking the position of the three sutures; in each space between two main ribs are two, or more commonly three, less prominent ridges, the whole number of projections thus varying from nine to twelve. The degree of prominence of the various ridges is very variable; in some cases only the three main ribs are clearly marked. The thickness of the sclerotesta between the ridges is about $\mathrm{I}-\mathrm{I} \cdot 25 \mathrm{~mm}$.

On the outside, the sclerotesta is abruptly succeeded by the delicate tissues of the sarcotesta, the inner layers of which consist of a continuous thin-walled parenchyma, passing over towards the exterior into a lax tissue, with large and definite lacunae between the cells. This zone, owing to its weak construction, is seldom well preserved, and its usually collapsed condition prevents us from giving any accurate estimate of the total thickness of the sarcotesta in the natural state, which must certainly have exceeded $2 \mathrm{~mm}$. The lacunar zone had not previously been distinguished. The whole is bounded externally by the limiting layers to which Mr. Wild first called attention. They consist of a hypoderma formed of one or sometimes two series of columnar cells, resembling a palisade-tissue. Beyond this is the true epidermis, composed of small, often nearly square cells. This layer, which had not been noticed before, appears to have been always present, though it is only bere and there that it is found well preserved. Mr. Wild compared the limiting layers of the sarcotesta in Trigonocarpon as then known (i. e., without the small-celled epidermal layer) with the similar tissues on the exterior of the petiole in Medullosa anglica, and indicated the general agreement in structure between the two. It must, however, be pointed out that in the petiole the small-celled epidermal lajer has not yet been detected, and it appears that the epidermis itself, as well as the hypoderma, had a palisade-form. The agreement between the two structures thus seems, on our present knowledge, less close than Mr. Wild believed it to be.

The very long micropylar tube, triangular in section in its lower part, is bounded immediately by thick-walled tissue forming the prolongation of the sclerotesta; outside this there is a great development of the sarcotesta, appearing, as seen in the transverse sections, as a wide flat wing on either side of the micropyle (see the series of figures in Mr. Wild's paper). This is limited externally by the usual hypoderma and epidermis. How far the flattened, wing-like form was natural is difficult to determine. There has certainly been some loss of tissue, so that the form in the natural state was less flattened than it now appears. It is doubtful, however, whether in this part of the seed the sectional form could ever have been circular.

One of the principal points to which our attention has been directed, is the distribution of the vascular supply through the seed. We find that there was a double bundle-system present. The outer system is situated in the sarcotesta, the bundles lying opposite the smaller ridges of the sclerotesta; they have 
not been found opposite the three main ribs. The bundles are embedded in the inner, denser zone of the sarcotesta. These sarcotestal strands were evidently complete bundles with phloem as well as xylem, and from the best-preserved examples it appears that the xylem was of mesarch structure. The second vascular system of the seed (already observed by Hooker and Binney and by Oliver ${ }^{1}$ ) runs through the contracted zone of tissue lying between the sclerotesta and the membrane of the megaspore. We regard the tissue in question as representing the nucellus, which appears in this seed, as in Stephanospermum, described fully by Prof. F. W. Oliver ', to have been free from the integument, from the chalaza upwards. In good specimens there is a distinct layer of cells, like an epidermis, limiting the nucellus on the outside, just as is the case at the free tip of the nucellus in a modern Cycad and still more closely resembling the nucellar epidermis of Siephanospermum ${ }^{8}$. This specialized layer of cells, which appears to be continuous with the epidermis of the pollen-chamber, can be traced the whole length of the nucellus from the chalaza upwards, and not merely in the upper part as in Cycads. Hence it is clear that the internal vascular system must be regarded as belonging wholly to the nucellus and not to the integument as described by Miss Stopes in Cycas:

The nucellar vascular system is rather complex in its arrangement. Towards the base, where the nucellar vascular tissue springs from the chalazal strand, it forms for some distance a practically continuous sheath of tracheides; further up the seed the tracheides, which are much flattened tangentially, range themselves in more or less definite but still crowded longitudinal strands, which are connected by transverse anastomoses running in a tangential direction. There is no evidence of phloem in connexion with the nucellar tracheides. The nucellar system has been traced through the whole length of the nucellus almost to the base of the pollenchamber, and indications of tracheides have been detected even in the beak of the pollen-chamber itself.

The tracheal system of the nucellus springs from the upper end of the chalazal strand, where the latter terminates at the junction of sclerotesta with nucellus. The connexion of the outer, sarcotestal system with the chalazal strand has not yet been traced, but from the position of the bundles, the junction must have been as much as $4 \mathrm{~mm}$. below the base of the nucellus.

The tracheides, especially those of the chalazal bundle and of the sarcotestal strands, show, in longitudinal sections, the fine scalariform markings characteristic of the primary tracheides in Medullosa, a point of agreement on which we lay some stress.

The pollen-chamber, already indicated in some of the figures of Hooker and Binney", was described and more fully illustrated by Williamson ${ }^{\circ}$. The pollen-chamber itself forms a wide dome $2 \cdot 5-3 \mathrm{~mm}$. in diameter at the base. We have to add the new fact that this was provided at the top with a narrow beak or canal, not more than $300 \mu$ in diameter. Curiously enough, this interesting

1 Structure and Affinities of Stephanospermuns, p. 39 r.

8 Loc. cit.

- On the Donble Nature of the Cycadean Integument, Ann. Bot., vol. xix, Oct. I905. Beiträge zar Kenntnis d. Fortpflanzungsorgane d. Cycadeen. Flora, Bd. 4, 1904.

- Loc. cit., Pl. IV, Figs. 7, 8, and I2. 'Loc. cit., Pl. XIII and XIV, Figs. II3-Ir5. 
structure is best shown in one of the original Hooker and Binney sections, now preserved in the Binney Collection at Cambridge. The presence of a beak is obscurely indicated in the Williamson section (C.N. I478), shown in Fig. 114 of his Memoir before referred to. The beak, as shown in the Binney slide, is barely half a millimetre in length, but presumably it extended much further in the natural condition. The cells of its outer wall are distinguished by their palisade-form, and there is an inner layer of prosenchymatous elements, apparently of the nature of tracheides. The resemblance to the Cordaitean pollen-chamber as shown in Renault's well-known figure ${ }^{1}$ is rather striking, while there is also a fair agreement with the corresponding structures in a recent Cycadean ovule.

The conclusions which we have so far reached as to the structure of Trigonocarpon olivaeforme are thus the following:-

1. The sarcotesta was differentiated into an inner, comparatively dense, and an outer, lacunar zone, the whole bounded by a definite hypoderma and epidermis.

2. The nucellus, so far as can be ascertained, was free from the integument throughout its whole length.

3. The pollen-chamber was provided with a beak or canal, comparable to that in Cordaitean and Cycadean seeds.

4. The vascular system of the seed was a double one; the outer system consisting of bundles running free in the sarcotesta, while the inner formed a complex tracheal reticulum in the nucellus, including definite longitudinal bundles, and thus differing from Stephanospermum where the tracheal mantle 'is a continuous sheath without trace of local segregation into bundles".'

5. The two systems of bundles diverged from the chalazal supply-strand at very different levels.

6. The tracheides agree closely in minute structure with the primary tracheides of Medullosa.

The impression that Trigonocarpon is the seed of Medullosa has been gaining ground for some considerable time, although no evidence of actual continuity is known. The practically constant occurrence of Medullosa petioles (Myeloxylon) in slides showing Trigonocarpon, and the equally general association of the casts of the seeds with the pinnules of Alethopleris lonchitica, now known to belong to Medullosa, as well as the resemblance in the minute structure of the tracheides, all tend to make the presumption probably true.

Mr. Wild, in his paper before referred to, emphasized the similarity between the outer tissues of Trigonocarpon and those of the petiole of Medullosa anglica, but, as has been indicated earlier in this note, with our present knowledge, the resemblance does not seem quite as close as he supposed, owing to the apparent ausence of the small-celled epidermal layer in the petioles.

It will be best to postpone any discussion of the affinities of the seed, until we are able to publish our work in full.

KEw.

D. H. SCOTT.

A. J. MASLEN.

1 Tiges de la Flore Carbonifere, Pl. 17 , Fig. I5.

2 Oliver, loc. cit., p. $3^{67}$. 